University of Nebraska - Lincoln

DigitalCommons@University of Nebraska - Lincoln

Papers in the Earth and Atmospheric Sciences

Earth and Atmospheric Sciences, Department

10-1903

\title{
PRESENT KNOWLEDGE OF THE DISTRIBUTION OF DAIMONELIX
}

\author{
Erwin Hinckley Barbour \\ University of Nebraska-Lincoln
}

Follow this and additional works at: https://digitalcommons.unl.edu/geosciencefacpub

Part of the Earth Sciences Commons

Barbour, Erwin Hinckley, "PRESENT KNOWLEDGE OF THE DISTRIBUTION OF DAIMONELIX" (1903). Papers in the Earth and Atmospheric Sciences. 349.

https://digitalcommons.unl.edu/geosciencefacpub/349

This Article is brought to you for free and open access by the Earth and Atmospheric Sciences, Department of at DigitalCommons@University of Nebraska - Lincoln. It has been accepted for inclusion in Papers in the Earth and Atmospheric Sciences by an authorized administrator of DigitalCommons@University of Nebraska - Lincoln. 
Daimonelix when first discovered, in 1891 , was thought to be confined to the elevated tablelands of central Sioux County, Nebraska. In the meantime its range has been extended and it is now known almost throughout the entire Arikaree formation, a tract probably about five hundred miles in diameter, situated in Nebraska, Kansas, South Dakota, Wyoming and Colorado. The more fibrous forms of Daimonelix constitute a character so constant as to justify the name Fibrous Arikaree for the upper half of the formation. The writer has traced these fossils as represented by the fibrous forms as far south as Benkleman, on the Kansas-Nebraska line, as far east as Fullerton and Long Pine, Nebraska; as far north as Eagle Nest Butte and White Clay Butte, in the Sioux Indian Reservation in South Dakota; and as far west as Lusk, Guernsey and Bates Hole, in Wyoming. Wellauthenticated reports would include northeastern Colorado, but those places only are mentioned which have been visited personally by the writer. Daimonelix proper is much more restricted than are the fibrous forms. However, its range has been extended beyond the highlands of central Sioux County as far west as Lusk, Wyoming, and as far east as Eagle Nest Butte, South Dakota. 
$x_{s}$ This does not change essentially the original limits ascribed to Daimonelix, for outside of Sioux County, where they occur in enormous numbers, they are found sparingly.

In its wider distribution this singular fossil is thought to be represented by a specimen found in Peissenberg, Germany, and described by Dr. Ludwig von Ammon, 'Geognostischen 'Jahresheften,' 1900, under the title Vorkommen von 'Steinschrauben' (Dremonhelix) in der Oligocänen Molasse Oberbayerns.

Erwin H. Barbour.

The UnIVersity of Nebraska, December, 1902. 